\title{
Becoming an Expatriate: J.W. Davidson and the Brain Drain ${ }^{*}$
}

DOUG MUNRO

Wellington

A timely reminder that expatriatism is a long-standing issue in New Zealand national life was provided recently by the publication of James McNeish's highly publicised Dance of the Peacocks. ${ }^{1}$ McNeish's study attempts to dovetail the lives of five young New Zealanders of the 'depression generation', namely James Bertram, Geoffrey Cox, Dan Davin, Ian Milner and John Mulgan. ${ }^{2}$ Their links were tenuous and it is stretching a point to describe them as a 'group'. Nonetheless, there are commonalities. All but one (Mulgan) was a Rhodes Scholar, and - leaving aside the sad fact that Mulgan took his life at the age of 34 - only Bertram returned to see out his career in New Zealand. The others remained abroad and prospered in ways that would not have been possible in their homeland. So it was, too, with their contemporary J.W. (Jim) Davidson (1915-1973), who left New Zealand for postgraduate study in 1938 at the age of 22; he went on to become foundation Professor of Pacific History at the Australian National University and constitutional adviser to a succession of Pacific Island territories at the time of decolonisation. ${ }^{3}$

It is not simply that New Zealand has never been able to absorb all the talent it produces. It is also the case that some of this lost talent has had cause to feel distinctly unwanted. Although pakeha New Zealand was an immigrant society, there was soon a counter-thrust involving the export of human capital to more receptive and remunerative destinations. James Belich

Much of the research for this paper was conducted during my tenure as Harold White Fellow at the National Library of Australia. I am most grateful to Graeme Powell and the staff of the Library's Manuscripts Reading Room for their collegiality and assistance; and to Sigrid McCausland, who facilitated my research among the archives of the Australian National University. I also acknowledge that the Master, Fellows and Scholars of St John's College, Cambridge (through the good offices of the Archivist, Malcolm Underwood) allowed me access to some of their records relating to Davidson. Helpful comments on an earlier version were provided by Tim Beaglehole, Annette Fairweather, Peter Hempenstall, Ronald Hyam, Brij V. Lal, Wm Roger Louis and W. David McIntyre. Grateful thanks are also extended to Francis West. The fact that he and Davidson had serious differences as departmental colleagues in Canberra never prevented Professor West from encouraging my work or fair-mindedly responding to my enquiries. 
has coined the term 'cultural over-production', and goes on to observe that '[m]uch of this talent then buggered off overseas, of course, an enduring "expatriate game". ${ }_{4}^{4}$ Katherine Mansfield and Lord Rutherford are only the most notable examples of this brain drain. So much did Mansfield repudiate the rude colonial environment from which she fled that she is sometimes identified, at least implicitly, as a British writer. ${ }^{5}$ Indeed, with Mansfield we can usefully draw the distinction between expatriates, who feel positively toward their country from afar, and exiles, who feel a sense of betrayal: 'The exile feels separated from his country as a sinner feels separated from his god; but unlike the sinner, the exile feels that he has been true to his country and his country false'. ${ }^{6}$

Such was the ubiquity of expatriate New Zealanders that the historian Keith Sinclair was feted at 'Kiwi parties' wherever he went on his 1967 study leave. Back home he more soberly lamented: 'We have developed an education system which is perfectly geared to the export market. Our society offers powerful special financial disincentives to encourage trained brains to export themselves . . . . [I]t is not a trade which earns us overseas funds. It is a form of aid which we donate to the more advanced countries'; it also impoverished New Zealand's intellectual and cultural life. The reality was, and remains, that disproportionate numbers of talented New Zealanders have sought to escape a discouraging environment, and usually they have been disinclined to return. Davin was to write: 'What more natural than that any young man with scholarly or academic ambitions should be eager to go to a place [like Oxford] where he could perfect his skills? . . . And where, in the New Zealand of 1945, could I have found a job at all equivalent in interest or emolument to my job at the Clarendon Press?' ${ }^{8}$ Of course, there was a downside: as Sinclair ruefully remarked in his autobiography, Davin talked 'endlessly in Oxford about Otago, fifty years and more after he left, an Otago that had long ceased to exist'?

One can always find exceptions. Davidson's friend, the writer Eric McCormick, returned prematurely from Cambridge University in the 1930s because he felt that he had 'absorbed everything that England had to offer'. ${ }^{10}$ And the writer Janet Frame was persuaded to remain in New Zealand by the award of the 1965 Burns Fellowship at the University of Otago, which gave her both recognition and a measure of financial tenability. ${ }^{11}$ It is important to identify such exceptions given the more-than-justified perception that expatriatism is a significant national loss. In their general histories of New Zealand, W.H. Oliver and Michael King speak of the frustrations and lack of opportunities that forced abroad such luminaries as Mansfield, fellow writer Jessie Mackay ('neither rejoiced in her place of birth'), and artist Frances Hodgkins, all of whom earned reputations in Europe to which they could never have aspired in New Zealand. ${ }^{12}$ Indeed, the very title of 
Hodgkins' biography is The Expatriate..$^{13}$ Robin Hyde - another writer who committed suicide - also springs to mind. ${ }^{14}$ The brain drain, moreover, had a compounding effect: talented people left to escape the prevailing 'cult mediocrity and conformity', thus reinforcing the undesirable state of affairs. 'The country exports the cream and keeps the skimmed milk', wrote Sinclair, ${ }^{15}$ who went on to deplore the features of New Zealand life - 'demot[ing] ability', the 'de-emphasis on leadership' and 'the Prevention of Talent' - that led to the brain drain. ${ }^{16}$

In 1966, there was an attempt to itemise the sheer extent of the brain drain. There is an entry on 'Expatriates' in A.H. McLintock's Encyclopaedia of New Zealand, which incorporates the potted biographies of over 250 individuals, distinguished in both artistic endeavours and the professions, who were working overseas in places as far apart as Venezuela and Northern

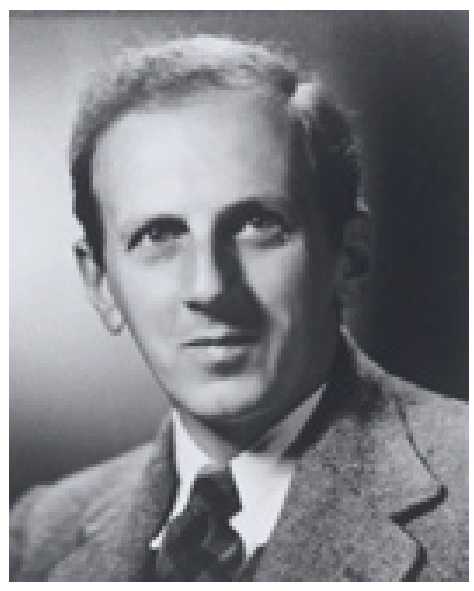
Rhodesia. ${ }^{17}$ Again, the implication is clear: these exiles enriched the cultural and professional life of other nations, especially England and Australia, to the corresponding impoverishment of New Zealand. It was a loss of intellectual capital that a country the size of New Zealand could ill-afford.

Jim Davidson is in the Encyclopaedia's listing of exiles. Whereas Sinclair remained in New Zealand - apart from wartime service - Davin and Davidson experienced a tension between love of their country and the professional demands of their calling which kept them abroad. The term 'country and calling' (or more accurately 'country or calling') was coined by an Australian Rhodes Scholar, the historian W.K. Hancock. ${ }^{18}$ The difference, however, was that Hancock eventually returned to his 'native land', enticed home by 'the call of the Kookaburra' (and, more to the point, a suitable posting at the Australian National University). ${ }^{19}$ Davin and Davidson lived, worked and died abroad, selfproclaimed Kiwis to the end but monuments to the brain drain.

\section{New Zealand background}

Jim Davidson was educated at Waitaki Boys' High School, which was then one of New Zealand's élite secondary schools and a bastion of the imperial ideal. ${ }^{20} \mathrm{He}$ proceeded to Victoria University College (VUC) and was awarded a first-class honours degree in 1938 for a thesis on Scandinavian settlement in New Zealand, which subsequently won the Walter Frewen Prize of the 
Royal Colonial Society. ${ }^{21}$ At that point the Department of Internal Affairs Centennial Atlas project needed a capable researcher to work on Maori tracks and waterways, and Davidson was recommended by his thesis supervisor and mentor, J.C. Beaglehole. ${ }^{22}$ Much as he enjoyed the work and the regard of his co-workers, Davidson was ambitious, and he soon sought the conventional royal road to academic success, namely a further degree from Oxbridge or London. He was shaken when beaten to an Oxford scholarship by Neville Phillips, later Professor of History, and then Vice-Chancellor, at the University of Canterbury. ${ }^{23}$ More successful was an application for a Strathcona Scholarship to Cambridge University. Davidson was given two years leave from the public service, with the blessing of the redoubtable J.W. (Joe) Heenan, Under-Secretary for Internal Affairs. He departed for England in August 1938, on the Tainui; and on the eve of his departure he wrote to his friend Miles Greenwood, with stilted melodrama:

I leave friends \& relatives \& a beloved country in search of excitement $\&$ novelty. So barren of virtue is one that amongst a million men \& even more one cannot find the means of full development of one's puny intellect, \& for the intellect, as the bringer of fame \& maker of money, one stands in awe. But enough $-{ }^{24}$

By strange coincidence, three fellow passengers, among them Neville Phillips, were also heading to England for postgraduate study in history, a marked contrast to the previous seven years when only two had gone to England for that purpose. ${ }^{25}$

On 1 October 1938 - his twenty-third birthday - Davidson enrolled for $\mathrm{PhD}$ studies, as a member of St John's College, Cambridge. He had come with the intention of writing on the Pacific Islands and he defined his thesis topic, which emerged as a seminal work in Pacific Islands historiography, as a study of the European penetration of the South Pacific to 1842. ${ }^{26}$ His supervisor was that gentle giant, Eric Walker, the Vere Harmsworth Professor of Naval and Imperial History, an eminent historian of empire but not au fait with the Pacific. ${ }^{27}$ Not that Davidson needed close supervision. Walker allowed him to get on with his work, read his chapter drafts carefully for internal consistency and, most important of all, was extraordinarily supportive in opening doors and generally furthering Davidson's cause.

When Davidson arrived in England there was no certainty that he would end up a permanent expatriate. He did, after all, only have two years leave from the Department of Internal Affairs. There was the clear expectation that he would return. It was by no means the norm that historians such as Davidson, who went to England for a further degree, would stay away. There were those from a slightly later generation who did so, such as H.J. Hanham (who found a position at the University of Manchester) and Richard Shannon 
(appointed to the University of Wales, Swansea). But for every one who remained abroad there were many more who came home, albeit with varying degrees of willingness. As W.H. Oliver, himself a reluctant returnee, has pointed out, New Zealanders 'did in fact constantly return, sometimes after lengthy intervals . . . . And greatly to our advantage - Harold Miller, John Beaglehole, Fred Wood (ex-Australian), William Morrell, Keith Sinclair, Angus Ross, Neville Phillips and Peter Munz, in the field of history alone ... . [E]xpatriatism and return are each determined by circumstance, opportunity and, above all, choice'. ${ }^{28}$ That being the case, what combination of circumstances militated against Davidson's return? The short answer is: that opportunities overseas did present themselves, and they were greater than anything on offer in New Zealand. This resulted in a gradual process of physical disconnection rather than an emotional disengagement in the sense of ceasing to self-identify as a New Zealander.

\section{Postgraduate studies at Cambridge}

Davidson settled into the life of a Cambridge postgraduate student readily enough. Once over the initial bout of desolation and loneliness, he joined into the round of College life and made lasting friendships - such as that with fellow student Peter Laslett, the later author of The World We Have Lost, who pioneered the methods of historical demography. Many years later, Laslett recalled Davidson's 'low voiced penetrating conversation on every subject'. ${ }^{29}$ Such was Davidson's conviviality and yearning for good company that at one stage, despite finding his thesis work absorbing, he almost lamented that friendships diverted him into socialising, musing it might be good for his work 'if I were among people I shunned \& disliked'. ${ }^{30}$ As well as his research in various London repositories, Davidson did the usual student things, such as going to movies and theatrical performances. Fond of travelling, Davidson was out and about when opportunity offered, always keen to see other parts of the country. He roamed Northern Ireland on a bicycle tour (with Miles Greenwood) during the entire vacation month of July 1939. On his first trip to Paris, he and a friend dared each other to eat snails in a restaurant, with both regretting their adventurousness. ${ }^{31}$ Davidson also kept up his New Zealand contacts. He was a dutiful son, writing to his family frequently and at length, and he was never backward in asking his father to send him the latest publications in New Zealand history and Maori affairs. He was also in regular contact with the Department of Internal Affairs, who would ask him to do a spot of research here and there for the Centennial Project. On another occasion, Davidson undertook research on behalf of G.H. Scholefield for the latter's Dictionary of New Zealand Biography. 
On the whole, Davidson enjoyed and made the most of his opportunities. At that time, postgraduate study in Britain was de rigueur for aspiring academics, but for many it was not an altogether pleasant experience. W.H. Oliver, who went to Oxford in the early 1950s, found that "Nothing in my upbringing, least of all the "home country" habits I had acquired in my upbringing, had prepared me for the carefully nuanced distancing techniques with which the English regulated their social relationships. I did not realise that the phrase "Oh, do you really think so?" was an invitation to conclude, not continue, a discussion'. ${ }^{32}$ Such encounters could be perplexing, distressing and damaging to one's self-esteem; and Davidson might well have fallen into this abyss. While on the surface possessed of easy social graces, at least with people he knew, he was essentially diffident and shy. As a friend later remarked, it was at first difficult to 'interpret his nervous, slightly tentative manner. He would venture a remark, then give a sidelong look as though to see how it went down. In fact . . . he was very sensitive, the sort of person who, once rebuffed, was unlikely to risk a second open approach, not from arrogance but for fear of rejection' ${ }^{33}$ His fellow student Peter Laslett provides insights lacking from Davidson's letters to his parents:

[Davidson] was an unusual, some would say strange personality, though some of this must have been due to what I took to be undeclared homosexuality with all the difficulties this would put in his way in such a society at such a time. ${ }^{34}$ His intellectual penetration, his unabashed irreverence and his desire and capacity to effect change, attracted me to him in addition to his unassuming gentle, companionable manner. What was discussed between us, apart from established historical doctrine in our relative fields - I was in what is called intellectual history, becoming a historical sociologist - was what was to become decolonization. This took the form of a deep dislike of the British Empire, its self-image and its propaganda, particularly as it related to the attitude towards 'primitive' people as subjects of the Imperial Crown. Because of the establishment of Imperial History as a 'discipline' at Cambridge and its relationship with the British Empire Society and so on, this caused social and personal problems for Jim . . . ${ }^{35}$

Davidson's distaste for Empire was in part a rejection of the pro-empire ethos of Waitaki Boys' High School, coupled with exposure to the liberalradical views of J.C. Beaglehole and F.L.W. Wood, his mentors at VUC. Such attitudes were less than welcome in English establishment circles, anticolonialism being associated with socialists and communists. ${ }^{36}$ Davidson somehow managed to navigate the shoals of disapproval - scraping his bottom against the occasional submerged rock and perhaps springing a leak, but without beaching himself or capsizing. In all likelihood he was shielded by Eric Walker, who thought highly of his student. The discomfort of the 
situation may help explain why Davidson sometimes spoke of the possibility of a brief return home to conduct historical research.

But he was in England for the long haul, especially with the onset of war in September 1939. The ghastly sense of foreboding that led up to the outbreak of hostilities was followed by an eerie atmosphere of uncertainty during the 'phoney war' in the winter of 1939. One uncertainty for Davidson was whether or not he would be conscripted. He was, he told his parents, 'quite unable to offer my services for any job requiring the taking of human life', ${ }^{37}$ and he was grateful for his father's and the College authorities' approval in the matter. As in New Zealand, there was considerable feeling that university work was an 'irrelevant' and 'untimely luxury' in the circumstances of war. ${ }^{38}$ In any case, Davidson would have made a hopeless soldier, even leaving aside his scruples about killing someone, and he would never have passed the medical examination for combat service. ${ }^{39}$ Asthmatic and prone to bouts of catarrh, he was neither robust nor physically coordinated. To his infinite relief, the Recruiting Board let him get on with his thesis work, which in turn was disrupted by the periodic closures of the London archival repositories and in some cases the removal of historical records to safer parts of the country. This created an additional problem for Davidson. At the outbreak of war he had enquired whether he could submit his thesis within two years, so as to meet the leave requirements of the New Zealand Civil Service. The regulations had been relaxed with the outbreak of war and it was now technically possible to do so, but the closure of archives put the solution beyond reach.

It was obvious that Davidson would not be able to finish his thesis in two years, but much less certain whether he could remain in England for a third year. What he did not want was to return to New Zealand with the lesser degree of MLitt, much less to go back empty-handed. There was also the unwelcome possibility that he might have to drop his thesis work until after the war, and in the meantime work in some essential war service. Naturally, he did not relish the prospects of such an interruption, wishing instead 'to bring this research to a satisfactory conclusion'. Nevertheless, he was prepared to volunteer for some sort of wartime work, such as fire watching, if that would enable him to stay in England. At the same time he did not wish 'to cut off the possibility of returning to the Internal Affairs Department'. So he applied, in the first instance, for six months extra leave of absence from New Zealand, and then for a further six months. To provide the wherewithal to remain in England he successfully applied for renewal of his Strathcona Scholarship and was awarded a Holland Rose Studentship and a Bartle Frere Exhibition. He had an unexpected stroke of good fortune: in applying for the Holland Rose Studentship he had asked Joe Heenan for a statement confirming that he was still a member of the 
New Zealand public service. Instead, the large-hearted Heenan provided Davidson with a glowing reference, surely in the knowledge that this might result in Davidson never returning to the Department. As Davidson remarked at the time, "he knows of course that I could not refuse a university job if I had the chance, which makes [his testimonial] more surprising. ${ }^{40}$

Clearly by this stage Davidson was setting his sights higher than a return to mapping Maori tracks and waterways for the Centennial Atlas of New Zealand; and some of the practical difficulties about remaining in England had been overcome in the short-term. But difficulties of another sort emerged with the downturn in his father's health. During the later months of 1940 Davidson was frantic with worry and wished more than ever that he could return to New Zealand for research. It can have scarcely helped his state of mind that his future prospects with the New Zealand public service were still unresolved, in the sense that he needed more leave than had been granted. When his father died, in early February 1941, Davidson was devastated, especially since he understood that his father was 'definitely on the mend'. ${ }^{41}$ He had not been close to his father in recent years, nor had their relations been entirely cordial; there were feelings of unassuaged guilt that he had not done more to mend fences. As he explained many years later, in a letter of condolence to a student in a similar position, and knowing exactly what degree of comfort to give: "when I got the news, I suffered remorse that I had done little to erase the friction born of my - inevitable - rejection of his authority, intellectual as well as parental. But the loss remains; and the consciousness that it is greater for others than oneself; and in this you have my warmest sympathy'. ${ }^{42}$

His father's death created financial as well as emotional difficulties, taking him down a road he might otherwise not have ventured. As well as his scholarships, Davidson had relied on an irregular allowance from his father, which now dried up. As he explained to his College tutor, he was reluctant to impose financially on his mother in the circumstances. ${ }^{43}$ Thesis or no thesis, he had to support himself; and none other than Eric Walker came to the rescue by recommending his student to Margery Perham of Nuffield College, Oxford, who was co-ordinating a major project on colonial legislatures in Africa. ${ }^{44}$ Everything was happening at once for Davidson. His father had just died; the air raids around Cambridge were stepping up; he was writing as much of his thesis as he could; and in May 1941 Miss Perham engaged him to write a monograph on the Northern Rhodesian Legislative Council. Davidson spent July and August in Oxford working full-time on his new assignment, and he continued to work on the book when he returned to Cambridge in September. In November he wrote to the New Zealand Public Service Commissioners asking for a further extension to his leave until September 1942. 
In any case, as Davidson realised, there was not much chance of him returning to New Zealand until the cessation of the war. He expected to 'become absorbed in one way or another in the [British] war machine'. ${ }^{45}$ He did, however, make an attempt in early 1941 to escape its clutches by applying to the British Council for 'a teaching post abroad'. His College tutor, Stanley J. Bailey, wrote a favourable testimonial, and provided Davidson with a copy. The following day, the tutor wrote a private and confidential follow-up letter expressing doubts that Davidson possessed 'the appearance of forcefulness and drive which you might wish your lecturers to show' - to which the British Council expressed its gratitude, saying that such confidential letters 'are particularly helpful'. ${ }^{46}$ Davidson would have been outraged had he discovered the duplicity. In the event it was for the better, because the next development was an extension of his leave-of-absence from the public service 'for the duration of the war and, you may take it, such further period as may be necessary to enable you to make up your mind whether you will be coming back to New Zealand'. The writer went on to say, 'the more I see of the work you are doing in England, the more I realise the improbability of your ever coming back to us. The British people have a habit of knowing a good man when they see one and not letting him go'. ${ }^{47}$ This letter was from none other than Joe Heenan, who had earlier written to Mrs Davidson:

I hope that one day [your son] will come back to New Zealand, but judging what he is doing at the other end of the world, I am afraid from our point of view, that we shall be able to offer him nothing in comparison with what looks likely to be in front of him in England. ${ }^{48}$

That is what happened, although it was by no means certain at the time. It was an extraordinarily generous gesture on the part of Heenan. As J.C. Beaglehole later lamented, if only Joe Heenan had been 'the pattern of our public servants' in New Zealand. ${ }^{49}$

\section{New opportunities}

Davidson spent the first half of 1942 completing his $\mathrm{PhD}$ thesis whilst also trying to keep the Northern Rhodesian work ticking along. He submitted his thesis in May and satisfied his examiners the following month at the oral. By this time the likelihood of being called up for active service was in the air and he viewed the prospect of joining the 'arrogant' army, even in a non-combat role, with unconcealed dismay. It then emerged that, although his thesis had been passed, he was still technically a student until actually graduating in October. In other words, he had a four-month reprieve to find alternative work that could be counted as contributing to the war effort - or else he could return to New Zealand, where intolerance toward pacifists and conscientious objectors was marked..$^{50}$ The immediate worry, however, 
was that Davidson no longer had income from scholarships. To be sure, Margery Perham wanted him in her stable, and made strenuous efforts to get the necessary funding, but uncertain that Miss Perham would locate the wherewithal he committed himself to a job with the Admiralty. No sooner this happened than Miss Perham did find the money!

She was very disappointed, Davidson not at all. In fact, he was 'overjoyed'. The Admiralty position not only removed 'the gloomy prospect of service in the ranks of the army. ${ }^{51}$ It also meant that Davidson was right hand man to Raymond Firth, author of The Primitive Economics of the New Zealand Maori (1929) and We, the Tikopia (1936), who had been seconded from his position as Professor of Anthropology at the London School of Economics. ${ }^{52}$ Davidson and Firth were soul mates. They had met the previous year and Firth was highly impressed with Davidson's ability and potential..$^{53}$ Mutual regard deepened into a life-long friendship. The Admiralty work was based at the Scott Polar Institute in Cambridge and involved the compilation of a series of volumes (variously known as the 'Admiralty Handbooks' or the 'Naval Intelligence Handbooks') which would provide broad-ranging information for British naval operations in the Pacific Islands. ${ }^{54}$ It was strenuous work. As well as authoring or co-authoring some 600 pages for the Admiralty Handbooks, ${ }^{55}$ Davidson was in charge during Firth's frequent illnesses. There were times when Davidson wilted. In reply to Miles Greenwood's enquiries:

'Burdens of work', you say, do they multiply. Well, yes. For I was not quite out of bed [with illness] when Firth went down with bronchitis, for the fourth time in as many months. All sorts of investigations have resulted: is there any sign of T.B. or any other organic disease? Most luckily there is not, but he has thrown over the editing of our current volume. I do it, in addition to as much of my own writing as I can't farm out (\& I can farm out very little). Of the remaining two members of our team, who were formerly kept up to the mark by Firth \& now have to be by me, one is about 35 , temperamental, \& extremely sensitive to criticism of work which he knows, but hates to admit, is frequently inaccurate $\&$ inadequate. So there are difficulties. ${ }^{56}$

On top of his Admiralty work, he continued to have responsibilities to the Nuffield project. The Northern Rhodesia book became a monkey on his back. On one occasion he referred to this 'seemingly unending problem', and in the same breath he heartily hoped that Miss Perham would be off to Jamaica so that her letters of enquiry would become less frequent. ${ }^{57}$ The problem persisted into the following year, he confessing to Greenwood:

Regrettable that one should attempt two things at once, but really activity is unceasing. I have been trying to find a moment to write for long, but 
without avail. Daytime \& evening I am either at the Polar Inst. or else [at my lodgings] writing (I refuse to do that without solitude). ${ }^{58}$

Davidson also served in the Home Guard and his election to a Fellowship of St John's College carried numerous associated duties. To cap things off, Firth urged him to collaborate in a war history, under the auspices of the Colonial Office. ${ }^{59}$ The offer was attractive, but his workload was too much as it was and he regretfully pulled out. He simply 'hate[d] the thought of going on \& every minute of [his] time having to be allocated to one job or another'. ${ }^{60}$ It was indeed a tough three years, whatever the opportunities they later opened up. The number of balls everyone was keeping in the air at one time in wartime Britain was beyond modern comprehension. Stress was constant. There was the threat of air raids to fracture sleep, too little food and coal, the blackout, only four inches of bath-water and even that not possible every day. The signposts had been removed from the roads to mislead any invading Germans. ${ }^{61}$ Closer to home, part of St John's College was requisitioned and occupied by the RAF.

The war delayed the careers of a number of aspiring academics who were called up for active service. ${ }^{62}$ But for those that stayed at home, wartime conditions created unprecedented employment opportunities, if they could tap into them. For a person of Davidson's obvious abilities the potential was there to ply his trade. He was doubly fortunate in not being obstructed by powerful people who objected to his personality, his views and the direct manner in which he expressed them. By his own account, Davidson was 'a rebel against established opinion'. ${ }^{63}$ This would not have gone over well in many quarters at Oxbridge, especially from a 'colonial'. As has been suggested, his views on colonial rule did him no good in pro-Empire circles in England. Nor did it help that he could be cutting as well as forthright when confronted with foolishness and pretentiousness; he had little time for over-rated people whom he regarded as pedestrian, uninspired or just plain stuffy. Had Bailey sensed that Davidson considered him 'unimaginative \& unoriginal', an 'excellent example' of the 'efficient "hacks" who are in universities', he may well have supported Davidson's application for a teaching position in Africa just to get rid of him. ${ }^{64}$

It may seem on the surface that openings only had to present themselves and Davidson would walk through. On the contrary, talent without preferment is futile, and Davidson had the extreme good fortune of having such influential patrons as Eric Walker, Margery Perham and Raymond Firth, as well as the historian W.K. Hancock, whom Davidson finally met when the war history possibility arose. These benefactors nullified his detractors, luckily for Davidson. One of the reasons was that he made such a favourable impression on the wives of his benefactors. But the detractors sometimes 
had their way, notably when Davidson's first attempt to secure a Fellowship at John's was unsuccessful. Davidson was bitterly disappointed; typically, he attributed his failure to the College Council's preference for 'mediocrities' in its choice of Fellows, and he then went on to identify by name those incumbents whom he considered had 'little standing as scholars' ${ }^{65} \mathrm{He}$ reapplied the following year, but with little enthusiasm or optimism. Firth shared his pessimism, feeling that Davidson was too 'uncompromising and independent'. But this time he was successful and he refrained from making caustic comments in his letters home, probably because he was too disgusted about the whole business to even be bothered. ${ }^{66}$

It is not hard to see why Davidson made enemies as well as friends, and why he embraced the idea of Cambridge but by no means all its denizens. Despite an attractive and endearing side to his personality ("[h]e wore his failings on his sleeve and was seldom averse to trailing his coat, but in matters of delicacy, academic or human, his counsel was discreet, wise and humane ${ }^{67}$ ) he had 'a wicked and subtle sense of humour'. ${ }^{68}$ The latter, often more wicked than subtle, frequently got him into trouble. Then there was the 'unabashed irreverence' and a pronounced unorthodoxy of style and substance that resulted in Davidson being regarded in some quarters as a strange and unpredictable New Zealander, rather than 'one of us'. ${ }^{69}$ Strong convictions combined with independence of mind and more than occasional indiscretion made him stand apart, and he was not the sort of person to cultivate the people whose support he needed but whom he did not respect. He made little attempt to hide his feelings, they reacted accordingly, and he was perhaps fortunate that this did not translate into a return passage to New Zealand.

\section{Consolidating his position}

Davidson's sponsors prevailed, fortunately for him, because there was not much going in New Zealand. In August 1943 he weighed up the possibilities of securing employment in New Zealand:

I don't suppose I can come to any conclusions as to where I want to get a job until jobs start getting offered again. There will have to be some reshuffling in the history departments in N.Z. within the next few years - the professors will have to think about retiring (Prof. Elder in Dunedin has been rather failing in health for some years past; \& Prof. Hight in Ch.Ch. is over 70, I should imagine.) If a satisfactory position in N.Z. were offered me I assume that I would take it. But one needs to display a certain amount of caution . . . . One could easily get involved in a mass of routine teaching which left no time for research; \& once out of England it is very difficult to get back if one should want to. There are a good many men in the N.Z. University as it is who have 
arrived in the country, enthusiastic \& full of original ideas, \& been gradually turned away from their proper jobs - content just to turn out some lectures year after year \& filling their time with golf or something similar. To outsiders they still appear learned \& scholarly but those who are nearer to their line of work see how unsatisfactory their position is. Of course, some still manage to overcome the difficulties. Dr. Beaglehole, for example, will always remain a first class scholar (though I hope I never lecture as badly as he does). So the position is, I think, that I would be foolish to return to N.Z. to a poor job: it would be better to wait for something satisfactory. ${ }^{70}$

One could also get involved in a mass of routine teaching in Cambridge, and Davidson started to run that risk himself. He had to take over Eric Walker's lectures on colonial history when his former supervisor visited his native South Africa; he taught colonial service probationers, and many of those from Africa and Jamaica were not terribly proficient in English; he was on the History Faculty Committee; and there was always a rush to prepare his lectures, which he did not enjoy giving.

But there were numerous benefits that could not be replicated in New Zealand. To begin with, his association with John's provided 'quite remarkable chances of meeting people'. ${ }^{71} \mathrm{He}$ also wrote an impressive review article of the second volume of the prestigious Cambridge History of the British Empire, which was at once authoritative and anti-colonialist. ${ }^{72}$ Davidson never expected such an opportunity to come the way of someone so junior. At the beginning of 1947 Davidson was appointed University Lecturer in Colonial History and he was instrumental in establishing the famous 'The Expansion of Europe' course. A remarkable feature of his new appointment was the firepower he was able to command in his choice of referees; in addition to Firth, Perham and Walker, there was the historian E.A. Benians and the geographer H.C. Darby. ${ }^{73}$ Despite his remarks about the lecturing capabilities of Beaglehole (whom he otherwise held in the highest regard), Davidson himself was not particularly adept on the podium. But he had a rare ability to see talent in students that others had overlooked, to identify the interests and needs of a student, and to inspire on a one-to-one basis. His former Cambridge students George Shepperson and Paul Hair, who became history professors at Edinburgh and Liverpool respectively, both acknowledged that they would never have entered academic life but for Davidson's encouragement and support. ${ }^{74}$

\section{From Cambridge to Canberra, via Samoa}

Davidson finally got the chance to return to New Zealand, on research leave, in late 1946. In the course of his eight years' absence he had established himself in England. So he was not looking for employment opportunities 
in New Zealand, but one of sorts came his way and he grabbed it with both hands. Davidson renewed his acquaintance with A.D. (later Sir Alister) McIntosh, whom he had known when working for Internal Affairs, and who by then was Permanent Head of the Prime Minister's Department. Faced with an upcoming visit of a United Nations trusteeship mission to Western Samoa, McIntosh persuaded the Prime Minister Peter Fraser to send Davidson there to report on the political situation and recommend steps towards Samoan self-government. As McIntosh recalled many years later, 'we wanted someone who would go and make a report on Samoa ... I knew Jim Davidson and I knew of his studies in the Pacific and I thought he would be suitable and I suggested him to Fraser and Fraser took my word for it . . . . You see we had no people of any academic qualifications ourselves. ${ }^{75}$ Beyond doubt, the first visit to Western Samoa as the Prime Minister's emissary, in April-July 1947, was a defining point in Davidson's life, a moment of intense self-discovery. The territory and its people made a profound impression on the 31-year old Davidson, resulting in an ongoing commitment that culminated in his being the Samoans' Constitutional Adviser in the final stages of decolonisation between 1959 and 1962, and the publication of his remarkable book Samoa mo Samoa in 1967. ${ }^{76}$

Back in England in September 1947, Davidson gave every indication of becoming ensconced. He settled back into the round of teaching and published an academic article on Western Samoa. ${ }^{77} \mathrm{He}$ gave regular talks and broadcasts on the Pacific Islands and on colonial history, and early the following year was asked to sit on a committee to advise the Secretary of State for the Colonies on the development of native courts and the position of native law in the colonies. Also in September 1947 he became involved in the Hakluyt Society's proposed definitive edition of Captain Cook's journals, his task being to put together a supplementary volume of essays on the scientific aspects of the voyages. ${ }^{78}$ In May the following year his Fellowship at John's was renewed for a further three years, without drama. That same month, at Walker's urging, he applied for the Beit Professorship in the History of the British Empire at Oxford University. At only 32 years of age, he gave himself no show and was pleasantly surprised at being runner-up in a strong field to Vincent Harlow (the Professor of Imperial History at the University of London). ${ }^{79}$

With so much to occupy him in England, it comes as no surprise that Davidson was indifferent when a small window of opportunity opened in New Zealand - at his alma mater, no less. Both F.L.W. Wood, the history professor at VUC, and John Beaglehole were proud and very fond of their star pupil. Wood asked, in 1948, if there was any possibility of Davidson spending a year at Victoria, and Davidson peremptorily told his mother: 'Of course there isn't: I couldn't get away'. ${ }^{80}$ It was an uncharacteristically 
ungracious remark, given that Wood was doing his best to secure a scarce academic opening for Davidson. But it did reveal that there was no competition between what New Zealand might offer compared to the professional openings, contacts and prestige of Cambridge, not to mention the future prospects that would surely open in England if he was prepared to bide his time. If he was to leave Cambridge, the magnet would have to exert far greater pulling power than New Zealand. Within weeks of Wood's enquiry, Davidson discovered that he was being considered for a chair at the newly-created Australian National University, which was being set up to further that country's post-war reconstruction and eventually to provide Australia with a research university of world standing. Firth and Hancock were Academic Advisors for the social sciences, and they agreed to recommend a chair of Pacific History, but only if Davidson occupied it. ${ }^{81}$ As Firth later explained:

Davidson was ... a man of highly original, almost idiosyncratic temperament, but his early experience of working with documents on the Rhodesian Council under the guidance of Margery Perham, his doctoral thesis, which Hancock admired very much . . . and his very considerable knowledge of Pacific literature which he gained working with me on these geographical handbooks, all of these meant that he was uniquely qualified [for the chair of Pacific History at ANU] ${ }^{82}$

Davidson certainly was interested, and while his sponsors were making the necessary arrangements he was further credentialing himself. He had allowed his name to go forward as New Zealand's nomination for the headship of the Social Development Section of the newly created South Pacific Commission, but decided instead to return to Western Samoa for eighteen months as Trusteeship Officer with specific responsibility for the advancement of Samoan self-government. ${ }^{83}$ Davidson firmly believed in the importance of harnessing scholarship to practical experience, that for 'an academic student of colonial government, the experience of actually occupying the key position in a colonial territory at the time of critical importance would be invaluable - a chance no one else studying in a university (e.g. Margery Perham) has come near having. ${ }^{84} \mathrm{He}$ was also convinced that he was indispensable to the Samoans. His work in Samoa was seen as an added bonus for the ANU position, and Firth clinched his argument for Davidson's appointment by pointing out that this scholar of excellent promise had an 'interest in practical problems and practical experience of them' that was part and parcel of his scholarly work. ${ }^{85} \mathrm{ANU}$ at the time placed high regard on academics who pursued a 'life of action', ${ }^{86}$ and when Davidson accepted his offer of appointment the University released a press statement that the new professor was 'regarded as one of the leading authorities on the history of the Pacific and current Pacific problems'. ${ }^{87}$ 
Davidson entered the ANU payroll in December 1950. He intended it as a stepping-stone for an Oxbridge chair, but his indifferent publishing record at ANU put paid to that. ${ }^{88} \mathrm{He}$ remained in Canberra, where he founded a distinctive school of Pacific Islands history, until his early death in 1973, aged $57 .{ }^{89}$ Reflecting the prevailing currents in the study of non-European history ${ }^{90}$ Davidson sought above all to replace imperial activity as the dominant organising theme of Pacific historiography with stress on the proactive role of Pacific Islanders in the shaping of outcomes. In a phrase, Davidson exhorted that Pacific Islands history be seen in terms of culture contacts and 'multi-cultural situations'. ${ }^{91} \mathrm{He}$ was also insistent that Pacific historians take into account the institutions and values of indigenous cultures in explaining the process of change. To these ends he encouraged an interdisciplinary approach, insisting on fieldwork and participant observation to gain the understanding that derives from immersion in the culture under study, as well as to counteract the biases and blind spots of documentary records of overwhelmingly European provenance. The new orthodoxy was expounded in the pages of the Journal of Pacific History, founded by Davidson in $1966 .{ }^{92}$

But fashions come and go, and as Kerry Howe has observed, it is clear that the 'days of cosy homogeneity, indeed hegemony, of the ANU school of island-centred culture contact studies are long gone'. ${ }^{93}$ There are now several epicentres, other specialist journals, and no one dominant approach to Pacific Islands history. ${ }^{94}$ Ironically, Davidson is today probably more highly regarded among historians of empire, whose subject he attempted to undermine, than by the generality of Pacific historians. In the historiographic chapter in The Cambridge History of the Pacific Islanders (1997), Davidson gets a cursory mention for 'mentor[ing] the reorientation of Pacific history' and for his involvement in the decolonisation of Oceania. ${ }^{95}$ By contrast, he is considered at much greater length in the historiographic volume of The Oxford History of the British Empire (2000), and more recently has been hailed by the imperial historian Ronald Hyam for his pivotal role in the establishment of the 'Expansion of Europe' course at Cambridge University. ${ }^{96} \mathrm{He}$ is respectfully recalled in the field he repudiated, and somewhat overlooked in the area he pioneered.

\section{Conclusion}

Throughout his life Davidson retained great affection for New Zealand: he visited the country frequently; he often spoke about his New Zealand friends, with whom he kept in contact; and he never ceased to identify himself as a New Zealander. He was an expatriate rather than an exile. Moreover, he was not one of those expatriates who 'wrote and spoke respectfully and affectionately of their homeland [only when] they were no longer living 
there. ${ }^{97}$ All the same, Davidson became an expatriate by conscious choice, which is another way of saying that he did not return to New Zealand through necessity. Neither did he simply drift into the expatriatism - that is, forget that time was passing, then wake up one morning to discover that it was too late to go home. Rather, Davidson had the means, the opportunity and the motive to become a permanent expatriate by conscious choice. $\mathrm{He}$ actively sought to stay in England beyond his two years leave from the New Zealand public service, and had the singular good fortune of Heenan's indulgence in the matter. He was then able to find appropriate academic work, starting with Margery Perham's colonial legislatures project, followed by the Naval Intelligence Division, a Fellowship (and teaching duties) at John's, and a lectureship in the Cambridge History Faculty. It was not the scarcity of university positions in New Zealand that kept him from returning. This was not a consideration; opportunities were continually opening for him abroad, culminating in the foundation chair of Pacific History at the Australian National University.

Davidson's letters to his family and to Miles Greenwood provide the means to reconstruct in some detail the process by which an individual became, and remained, an expatriate. But one should not over-generalise from a single case study. Despite the frequent lamentations at the prevalence of New Zealand expatriates, Davidson may well be exceptional rather than typical, at least of his generation and certainly of historians. It is a convoluted situation with multiple outcomes, depending on a mix of ambition, opportunity and personal circumstances. John Pocock left Canterbury for the United States where he concluded a distinguished career at The Johns Hopkins University. ${ }^{98}$ J.H.M. (Jock) Salmon, unable to obtain university positions in England, returned to New Zealand. After four years at Waikato, he left in 1969 for the more congenial pastures of Bryn Mawr College in Pennsylvania. ${ }^{99}$ Keith Sinclair, by contrast, had offers to go abroad but preferred to stay in Auckland: 'I did not want my boys to grow up Americans. Moreover, I would have had to give up New Zealand history, which I was determined not to do' ${ }^{100}$ By contrast again, Peter Munz arrived in New Zealand from Germany as a teenager, in 1940. He earned a Cambridge $\mathrm{PhD}$ - at St John's College, no less - and returned to New Zealand to resume teaching at VUC. He could easily have obtained an overseas appointment but preferred to stay in New Zealand, the country which had provided a refuge from fascist Europe and then given him his first professional opportunities..$^{101}$

Continuing to confine the discussion to historians, the impression is that far more returned than stayed away - that the majority of Kiwi historians who obtained overseas postgraduate qualifications were more or less compelled to return to their homeland, like it or not, because they could 
not secure academic positions overseas. Sometimes it is not clear-cut, as in the case of W.P. Morrell, who returned in 1946 as Professor of History at Otago. Morrell had earned a fine reputation as a historian of empire and was Reader of History at Birkbeck College, London. There was, he explained, "no magnetic attraction drawing me irresistibly back to New Zealand. I had been twenty-two years in England, had married a Welsh wife and made many good friends'. ${ }^{102}$ But he felt that further advancement was unlikely because his chosen field, the history of empire, was unfashionable among English historians, who were 'generally more interested in discussing how many oxen there were in a Domesday plough-team than they were in the history of the British empire.' ${ }^{103} \mathrm{He}$ also wanted 'to run [his] own show'. Hence his return to New Zealand in 1946. But he would have been disqualified from applying from the Otago professorship had his father still been Chancellor of the university.

Others had more scaled-down options. Davidson's 1938 shipboard companion Neville Phillips, a noted Anglophile, did not intend to return to New Zealand; indeed, he spent the rest of his life wanting to get back to England, and did so the moment he retired. But in 1946 he had a family to support so he wrote to J.H.E. Schroder, the editor of the Christchurch Press, asking for a job. (Phillips had been a journalist before going to England.) Schroder, who was on the Council of Canterbury University College, mentioned his name to the history professor, James Hight, and Phillips was promptly offered a lectureship. ${ }^{104}$ It was as easy as that; and within two years Phillips had succeeded Hight as professor and eventually became Vice-Chancellor. W.H. Oliver did not land on his feet so readily. Unable to secure an academic position in Britain, he was forced home to make an awkward and fitful 'renaturalisation'. ${ }^{105}$ Clearly, there are ambiguities and anxieties associated with returning as much as with leaving. Oliver rose to the top of his profession and eventually felt at home in New Zealand, recently admitting that he was glad that his various attempts to regain expatriate status were unsuccessful. ${ }^{106}$ His initial misfortune, as it seemed at the time, was to New Zealand's long-term benefit. But the fact remains that neither Oliver nor Phillips, if given the choice, would have made their careers at home. They would have stayed away and joined the brain drain; and Phillips did so in his retirement.

At the same time, expatriatism should be put into perspective. It is true that New Zealand has an embarrassing record of driving out talent, and there are many cases of New Zealanders remaining abroad because there is nothing to compare with the opportunities overseas. Conversely, many New Zealanders in the artistic field have deliberately chosen to return, despite the country's philistine reputation. ${ }^{107}$ What is often overlooked is that New Zealand has vicariously benefited from a brain drain from the 
other direction. In a paper aptly entitled 'What did New Zealand do to Scotland and Ireland?', Don Akenson points out that it was not only the disadvantaged and displaced who emigrated but also those with skills and capital that Scotland and Ireland could ill afford to lose. ${ }^{108}$ On a smaller scale Hitler's émigrés, those mostly-Jewish refugees from Mitteleuropa, were making good their escape from Nazi persecution between 1936 and 1939. Some 1,100 of that diaspora ended up in New Zealand, making a contribution to national life out of all proportion to their numbers. ${ }^{109}$ Then there is the present immigration policy, which is slanted heavily in favour, as is the case with most other countries, of receiving people with desired skills.

Davidson, Morrell, Phillips and Oliver went to England for a further university degree at a time when that was the done thing. Since the 1960s, the United States and Australia have been alternative destinations. But increasingly New Zealand historians have been happy enough to get their $\mathrm{PhDs}$ at home, especially with a more nationalist outlook and the increasing ascendancy of New Zealand history as a university teaching subject - a development which lends support to James Belich's notion of a 'recolonisation' (a tightening of links with Britain from the 1880s) ultimately giving way to 'decolonisation' (cultural renaissance and distinctiveness). ${ }^{110}$ A further development in the 1960s was the unprecedented growth of universities ${ }^{111}$ which redirected the brain drain in academic historians. Australian academic salaries far outstripped those in New Zealand, resulting in many New Zealand historians taking up more lucrative university positions across the Tasman. Davidson was only the first New Zealander to become a professor in the broad area of modern history at an Australian university. ${ }^{112}$ At least seven others have followed: Trevor Wilson (Adelaide), Brian Dalton (James Cook), Patrick O’Farrell (UNSW), John Salmond (La Trobe), Duncan Waterson (Macquarie), Patricia Grimshaw (Melbourne) and Alan Ward (Newcastle, whose PhD was supervised by Davidson). Like Davidson, they had options and opportunities, and they made the most of their element of choice and room for manoeuvre. They went to Australia and stayed there; and New Zealand once again lost out.

1 James McNeish, Dance of the Peacocks: New Zealanders in Exile in the Time of Hitler and Mao Tse-Tung, Wellington, 2003.

2 See Keith Ovenden, A Fighting Withdrawal: The Life of Dan Davin, Writer, Soldier, Publisher, Oxford, 1996; Vincent O'Sullivan (ed.), Intersecting Lines: The Memoirs of Ian Milner, Wellington, 1993; Vincent O'Sullivan, Long Journey to the Border: A Life of John Mulgan, Auckland, 2003. There is more on Davin in Donald Harman Akenson, Half the World from Home: Perspectives on the Irish in New Zealand, 1860-1950, Wellington, 1990, pp.89-122. 


\section{Journal of New Zealand Studies}

3 See the entries on Davidson in Australian Dictionary of Biography, Melbourne, 1993, vol.13, p.579 (by Donald Denoon); Dictionary of New Zealand Biography, Auckland/ Wellington, 2000, vol.5, pp.135-36 (by Doug Munro).

4 James Belich, 'Hitching a Ride from History', in Press (Christchurch), 6 August 2001, p.7 (I owe this reference to Bruce Harding).

5 Dina Wallace, Sisters and Rivals in British Women's Fiction, 1914-39, London, 2000, pp.18, 30, 38-39, 77, 79-80.

6 Richard Ellmann, 'Becoming Exiles', in his collected essays, A Long the Riverrun, Vintage Books edition, 1988, p.33.

7 Keith Sinclair, 'Exporting Expertise', in New Zealand Listener, 9 February 1968, p.5.

8 Dan Davin, 'Correspondence', in New Zealand Journal of History, vol.13, no.1, 1979, pp.104-05.

9 Keith Sinclair, Halfway Round the Harbour: An Autobiography, Auckland, 1993, p.89.

10 James Smithies, “Modernism or Exile”: E.H. McCormick and Letters and Art in New Zealand', in History Now, vol.9, no.4, 2004, p.18. Instead of staying on to complete a $\mathrm{PhD}$ thesis, McCormick took the degree of MLitt.

11 Michael King, Wrestling with the Angel: A Life of Janet Frame, Auckland, 2000, p.300.

12 W.H. Oliver, The Story of New Zealand, London, 1960, pp.283-84; Michael King, The Penguin History of New Zealand, Auckland, 2003, pp.318-19.

13 Eric McCormick, The Expatriate: A Study of Francis Hodgkins, Wellington, 1954.

14 See Derek Challis and Gloria Rawlinson, The Book of Iris: A Biography of Robin Hyde, Auckland, 2002.

15 Keith Sinclair, A History of New Zealand, Harmondsworth, 1959, p.277.

16 Keith Sinclair, 'The Historian as Prophet', in M.F. Lloyd-Pritchard (ed.), The Future of New Zealand, Christchurch, 1964, pp.130, 136-37.

17 A.H. McLintock (ed.), An Encyclopaedia of New Zealand, Wellington, 1966, vol.1, pp.573-604.

18 W.K. Hancock, Australia, London, 1930, p.vii; Country and Calling, London, 1954, pp.125-6, 245, 247.

19 S.G. Foster and Margaret N. Varghese, The Making of the Australian National University, 1946-1996, Sydney, 1996, pp.43-50, 129-35.

20 A.R. Tyrrell, Strong to Endure: Waitaki Boys' High School, 1883-1958, Oamaru, 1983, pp.280, 283; Ian Milner, Milner of Waitaki: Portrait of The Man, Dunedin, 1983.

21 Spike: The Victoria College Review, no.66, 1938, pp.34-35, Victoria University College Calendar, 1939, p.180; Donald H. Simpson (ed.), The Manuscript Catalogue of the Library of the Royal Commonwealth Society, London, 1975, p.23.

22 Minutes of Meeting of the Atlas Sub-Committee . . 10th March 1938; J.W. Heenan to Public Service Commissioners, 11 April 1938, Alexander Turnbull Library (hereafter ATL), MSS-Papers-0230/001. An account of the Centennial Atlas project, by a participant, is Eric McCormick, An Absurd Ambition: Autobiographical Writings (edited by Dennis McEldowney), Auckland, 1996, chpt.10.

23 JWD to Miles Greenwood, 12 July 1938. Miles Greenwood (1913-1992) went to Hereworth School with Davidson during the time the Davidson family lived in Hawkes Bay. They became lifelong friends, and they saw much of each other when living in England at the same time; Greenwood was studying drama at the Old Vic. Davidson's letters to Greenwood were kindly loaned to me by the latter's niece, Caroline Greenwood, and then deposited in the National Library of Australia, MS 9805 (hereafter cited as Greenwood Papers). 


\section{Becoming an Expatriate: J.W. Davidson and the Brain Drain}

24 JWD to Greenwood, 15 August 1938 (emphasis in original), Greenwood Papers.

25 JWD to his mother, 26 August 1938, Papers of J.W. Davidson (hereafter Davidson Papers), National Library of Australia, MS 5105, Box 64.

26 J.W. Davidson, 'European Penetration of the South Pacific, 1779-1842', PhD thesis, Cambridge University, 1942. See also Davidson's Tutorial File, Archives of St. John's College, Cambridge.

27 On Walker generally, see Ken Smith, The Changing Past: Trends in South African Historical Writing, Athens, Ohio, 1989, pp.121-31; Christopher Saunders, The Making of the South African Past: Major Historians on Race and Class, Totowa, 1988, pp.112-15.

28 W.H. Oliver, 'The Gang of Five', in New Zealand Books, vol.13, no.4, October 2003, p.5.

29 Peter Laslett, personal communication, May 1999. See the obituary of Laslett in the Guardian, 17 November 2001.

30 JWD to Greenwood, 4 November 1939, Greenwood Papers.

31 JWD to his mother, 12 April 1939, Davidson Papers, Box 64.

32 W.H. Oliver, Looking for the Phoenix: A Memoir, Wellington, 2002, p.89.

33 Nancy Phelan, Pieces of Heaven: In the South Seas, Brisbane, 1999, p.33.

34 There has been considerable speculation on Davidson's sexuality. The general feeling at ANU was that he was a closet homosexual in inclination if not in practice; but I have been unable to establish whether or not this was the case.

35 Peter Laslett, personal communication, May 1999.

36 Nicholas Owen, 'The Critics of Empire', in Judith M. Brown and Wm Roger Louis (eds), The Oxford History of the British Empire: vol.4. The Twentieth Century, Oxford, 1999, pp.188-211; Stephen Howe, Anticolonialism and British Politics: The Left and the End of Empire, 1918-1964, Oxford, 1993; Patricia Pugh, Educate, Agitate, Organize: 100 Years of Fabian Socialism, London, 1984, chpt.18.

37 JWD to his mother, 3 September 1939, JWD to his parents, 7 October 1939, Davidson Papers, Box 64.

38 Nancy M. Taylor, The New Zealand People at War: The Home Front, Wellington, 1986, vol.2, pp.1148-49.

39 Some New Zealanders of Davidson's acquaintance not only enlisted but went on to write official combat histories in the 'New Zealand in the Second World War, 1939-1945' series: D.M. Davin, Crete, Wellington, 1953; N.C. Phillips, Italy: Volume 1, The Sangro to Cassino, Wellington, 1957; Angus Ross, 23 Battalion, Wellington, 1959. Davidson promoted the idea of the historian as participant, but temperamental and medical reasons ruled him out of active combat.

40 JWD to his mother, 26 April 1940, 23 May 1940, Davidson Papers, Box 64; JWD to Heenan, 28 August 1940, Heenan Papers, ATL, MS Papers 1132/048; Davidson's Tutorial File, St John's College, Cambridge.

41 JWD to his father, 29 September 1940, JWD to his mother, 11 October 1940, Davidson Papers, Box 64; JWD to Greenwood, 11 October 1940, 3 November 1940, Greenwood Papers.

42 JWD to Peter Corris, 19 June 1967 (provided by P.R. Corris). Corris went on to become Australia's foremost writer of detective fiction, and the creator of the recurring character Cliff Hardy. See Peter Cotton, 'Peter Corris on his Craft, and Cliff Hardy', National Graduate (Canberra), vol.2, no.3, 1991, pp.7-9; Clive Moore, 'Writing for Fun: Interview with Peter Corris, Author of the Cliff Hardy Detective Novels', Clues: A Journal of Detection, vol.21, no.2, 2000, pp.57-66. 


\section{Journal of New Zealand Studies}

43 JWD to Stanley J. Bailey, 11 February 1941, Davidson's Tutorial File, St John's College, Cambridge. Bailey was Bull Professor of Law at Cambridge University.

44 JWD to his mother, 22 March 1940. See also Patricia Pugh, 'Margery Freda Perham, 1895-1982', in Proceedings of the British Academy, vol.111, 2001, pp.617-33.

45 JWD to Bailey, 11 February 1941, Davidson's Tutorial File, St John's College, Cambridge.

46 Bailey to Secretary, British Council, 19 February 1942, and (private and confidential) 20 February 1942, Secretary, British Council to Bailey, 24 February 1942, Davidson's Tutorial File, St John's College, Cambridge; JWD to his mother, 1 March 1942, Davidson Papers, Box 65.

47 Heenan to JWD, 13 April 1942, Heenan Papers, ATL, MS Papers 1132/048.

48 Heenan to Mabel Davidson, 18 March 1942, Heenan Papers, ATL, MS Papers $1132 / 048$.

49 J.C. Beaglehole, 'The New Zealand Scholar', in Peter Munz (ed.), The Feel of Truth, Wellington, 1969, p.247.

50 David Grant, Out in the Cold: Pacifists and Conscientious Objectors in New Zealand during World War II, Auckland, 1986, chpts.2-3.

51 JWD to his mother, 13 July 1942, Davidson Papers, Box 65.

52 See Michael W. Young, 'Raymond William Firth, 1901-2002', in Journal of Pacific History, vol.38, no.2, 2003, pp.277-80.

53 JWD to his mother, 4 March 1941, Davidson Papers, Box 64.

54 Naval Intelligence Division [of the British Admiralty], Pacific Islands (Geographical Handbook Series), 4 vols, [no place of publication], 1943-1945. Peter Corris's very first Cliff Hardy novel (The Dying Trade, Sydney, 1980) has Hardy consulting the complete set of Admiralty Handbooks to check a New Caledonia angle to a mystery. He has met in a Canberra pub a long, thin professor - obviously based on Davidson - who tells him about the Handbooks and where to buy a second-hand set. Corris dedicated another of his novels ('Beverly Hills' Browning, Ringwood, 1987) 'For the memory of J.W. "Jim" Davidson'.

55 R. Gerard Ward, 'Davidson's Contribution to the "Admiralty Handbooks"', in Journal of Pacific History, vol.29, no.2, 1994, pp.238-40.

56 JWD to Greenwood, 26 February 1944, Greenwood Papers.

57 JWD to his mother, 13 February 1943, Davidson Papers, Box 65. The Northern Rhodesian Legislative Council was finally published, to favourable reviews, in 1948. J.W. Davidson, The Northern Rhodesian Legislative Council (Studies in Colonial Legislatures, vol.3, edited by Margery Perham), London, 1948.

58 JWD to Greenwood, 19 April 1944, Greenwood Papers.

59 See Denys Hay, 'British Historians and the Beginnings of the Civil Histories of the Second World War', in M.R.D Foot (ed.), War and Society, London, 1973, pp.39-57; Jose Harris, 'Thucydides Amongst the Mandarins: Hancock and the World War II Civil Histories', in D.A. Low (ed.), Keith Hancock: The Legacies of an Historian, Melbourne, 2001, pp.122-48.

60 JWD to his mother, 6 August 1944, Davidson Papers, Box 65.

61 Arthur Marwick, The Home Front: The British and the Second World War, London, 1976; Jose Harris, 'War and Social History: Britain and the Home Front During the Second World War', Contemporary Social History, vol.1, no.1, 1992, pp.17-35.

62 See Eric Hobsbawm, Interesting Times: A Twentieth-Century Life, London, 2002, p.302.

63 J.W. Davidson, 'Understanding Pacific History: The Participant as Historian', in Munz (ed.), The Feel of Truth, p.30. 


\section{Becoming an Expatriate: J.W. Davidson and the Brain Drain}

64 JWD to his mother, 8 June 1942, Davidson Papers, Box 65. Davidson's unconventional 'style' and cultivated dishevelment became more pronounced when he became a professor in Canberra. A newly-arrived colleague in 1952 recalled 'Jim Davidson, wearing short shorts, an open-necked short-sleeved shirt, thongs on bare feet, with the profile of one of the younger, slightly decayed Roman emperors, at first meeting wanting to know the latest Cambridge history faculty and college gossip. Only after that did we return to Pacific history'. Francis West, 'Migrant Historian', typescript, 2001, p.26, J.C. Beaglehole Room, Victoria University Library.

65 JWD to his mother, 16 May 1943, Davidson Papers, Box 65.

66 JWD to his mother, 24 April 1944, 4 May 1944, Davidson Papers, Box 65. Whatever Davidson thought, St John's College took the election of Fellows seriously. Reports were solicited reports from senior academics on the quality of a candidate's written work, asking also whether it indicated future potential. The reports on Davidson are by G.N. Clark (the Regius Professor of History at Cambridge), W.K. Hancock, Raymond Firth and Eric Walker. Archives of St John's College, D93.69 (Clark and Hancock), D93.72 (Firth and Walker).

67 O.H.K. Spate, 'And Now There Will Be A Void: A Tribute to J.W. Davidson', in Journal of Pacific Studies, vol.20, 1996, p.21. Spate was foundation Professor of Geography at ANU and a close friend and colleague of Davidson.

68 Phelan, Pieces of Heaven, p.33.

69 West, 'Migrant Historian', p.21; and further information from Professor West.

70 JWD to his mother, 2 August 1943, Davidson Papers, Box 65.

71 JWD to his mother, 24 June 1944, Davidson Papers, Box 65.

72 J.W. Davidson, 'The History of Empire', in Economic History Review, vol.16, no.1, 1946, pp.68-73.

73 Ronald Hyam, 'The Study of Imperial and Commonwealth History at Cambridge, 1881-1981: Founding Fathers and Pioneering Research Students', in Journal of Imperial and Commonwealth History, vol.29, no.3, 2001, pp.81, 98n.31; West, 'Migrant Historian', p.21.

74 George Shepperson, P.E.H. Hair and Doug Munro, 'J.W. Davidson at Cambridge University: Some Student Evaluations', in History in Africa, vol.27, 2000, pp.215-27; JWD to his sister, 15 September 1956, Davidson Papers, Box 66.

75 Sir Alister McIntosh (interview by F.L.W. Wood and Mary Boyd, 2 December 1975), typescript, Alexander Turnbull Library, 80-413. See also Mary Boyd, 'The Decolonisation of Western Samoa', in Munz (ed.), The Feel of Truth, p.64; Michael Bassett with Michael King, Tomorrow Comes the Song: A Life of Peter Fraser, Auckland, 2000, p.326.

76 J.W. Davidson, Samoa mo Samoa: The Emergence of the Independent State of Western Samoa, Melbourne, 1967; Doug Munro, 'J.W. Davidson and Western Samoa: University Politics and the Travails of a Constitutional Adviser', in Journal of Pacific History, vol.35, no.2, 2000, pp.195-211.

77 J.W. Davidson, 'Political Development in Western Samoa', in Pacific Affairs, vol.21, no.2, 1948, pp.136-49.

78 JWD to his mother, 15 February 1948, Davidson Papers, Box 65. Davidson was unable to bring this project to fruition. The story will be told in Tim Beaglehole's forthcoming biography of J.C. Beaglehole.

79 JWD to his mother, 23 May 1948, Davidson Papers, Box 65.

80 JWD to his mother, 17 June 1948, Davidson Papers, Box 65.

81 JWD to his mother, 6 July 1948, Davidson Papers, Box 65.

82 Sir Raymond Firth (interview by Margaret Murphy, 7 June 1974), typescript, p.21, Oral History Section, National Library of Australia. Professor Firth kindly allowed me to quote from this source. 


\section{Journal of New Zealand Studies}

83 Susan Woodburn, Where Our Hearts Still Lie: A Life of Harry and Honor Maude in the Pacific Islands, Adelaide, 2003, p.220; Davidson, Samoa mo Samoa, p.192.

84 JWD to his mother, 31 October 1948, Davidson Papers, Box 65.

85 'Extract from Letter from Professor Firth, dated 6/7/49', Personal File of J.W. Davidson, 6.2.1.3(c), folio 2, ANU Central Archives (my emphasis).

86 Foster and Varghese, The Making of the Australian National University, p.51.

87 'Note for File', Personal File of J.W. Davidson, 6.2.1.3, folio 7, ANU Central Archives (my emphasis).

88 Davidson to his mother, 6 July 1948, Davidson Papers, Box 65; Francis West, personal communication, 25 May 1999.

89 Former members of Davidson's Department of Pacific History have provided reminiscences: Neil Gunson, 'The Study of Pacific History', in Brij V. Lal (ed.), Pacific Islands History: Journeys and Transformations, Canberra, 1992, pp.1-13; Dorothy Shineberg, 'The Early Years of Pacific History', in Journal of Pacific Studies, vol.20, 1996, pp.1-16.

90 See John W.R. Smail, 'On the Possibility of an Autonomous History of Modern Southeast Asia', in Journal of Southeast Asian History, vol.2, no.2, 1962, pp.72-102; J.D. Fage, 'British African Studies since the Second World War: A Personal Account', in African Affairs, no.88, 1989, pp.397-413.

91 J.W. Davidson, The Study of Pacific History: An Inaugural Lecture Delivered in Canberra on 25 November 1954, Canberra, 1955.

92 The books that best illustrate the Davidson tradition are: J.W. Davidson and Deryck Scarr (eds), Pacific Islands Portraits, Canberra, 1970; K.R. Howe, Where the Waves Fall: A New South Sea Islands History from First Settlement to Colonial Rule, Sydney, 1984.

93 K.R. Howe, 'The Future of Pacific Islands History: A Personal View', in Lal (ed.), in Pacific Islands History, p.229.

94 See Barrie Macdonald, “Now An Island Is Too Big”: Limits and Limitations of Pacific Islands History', and Doug Munro, 'The Isolation of Pacific History', both in Journal of Pacific Studies, vol.20, 1996, pp.23-44, 45-68, respectively.

95 Jocelyn Linnekin, 'Contending Approaches', in Donald Denoon et al (eds), The Cambridge History of the Pacific Islanders, Cambridge, 1997, pp.20, 25.

96 Wm. Roger Louis, 'Introduction', and Bronwen Douglas, 'Imperial Flotsam? The British in the Pacific Islands', both in Robin W. Winks (ed.), The Oxford History of the British Empire, vol.5: Historiography, Oxford, 2000, pp.32-33, 370-72, respectively; Hyam, 'The Study of Imperial and Commonwealth History at Cambridge', pp.81-84.

97 King, The Penguin History of New Zealand, p.417.

98 Occasionally, a New Zealand academic expatriate writes at length about his experiences. See Michael Jackson, At Home in the World, Durham, NC, 1995.

99 Salmon to Wood, 5 February 1969, Papers of F.L.W. Wood, ATL, MS-Papers-90-006$07 / 11$.

100 Sinclair, Halfway Round the Harbour, p.137.

101 See J.L. Roberts, 'A Personal Tribute', and W.H. Oliver, 'Petrus Contra Mundum', both in Miles Fairbairn and W.H. Oliver (eds), The Certainty of Doubt: Tributes to Peter Munz, Wellington, 1996, pp.20-27, 28-37, respectively; David Venables, 'Peter Munz', in James N. Bade (ed.), Out of the Shadow of War: The German Connection with New Zealand in the Twentieth Century, Melbourne, 1998, p.173n.4. Davidson helped Munz get accepted into St John's College as a PhD student. JWD to his mother, 15 September 1945, 2 March 1946, Davidson Papers, Box 65.

102 W.P. Morrell, Memoirs, Dunedin, 1979, p.106. 


\section{Becoming an Expatriate: J.W. Davidson and the Brain Drain}

103 Ibid., p.49.

104 I am grateful to Jock Phillips for this information.

105 Oliver, Looking for the Phoenix, esp. pp.93, 108, 121-22.

106 Oliver, 'The Gang of Five', p.5.

107 A number of such people have penned their memoirs in Margaret Clark (ed.), Godwits Return, Wellington, 1992. Several of the essays in Michael King (ed.), Pakeha: The Quest for Identity in New Zealand, Auckland, 1991, also address the question of a sense of belonging to New Zealand being heightened by overseas experience.

108 Donald Harman Akenson, 'What did New Zealand do to Scotland and Ireland?', in Brad Patterson (ed.), The Irish in New Zealand: Historical Contexts and Perspectives, Wellington, 2002, pp.185-200.

109 In addition to Bade (ed.), Out of the Shadow of War, see Ann Beaglehole, A Small Price to Pay: Refugees from Hitler in New Zealand, 1936-46, Wellington, 1988; Brigitte Bönisch-Brednich, Keeping a Low Profile: An Oral History of German Immigration to New Zealand, Wellington, 2002; John Mansfield Thomson, Into a New Key: The Origins and History of The Music Federation of New Zealand, Inc. 1950-82, Wellington, 1985, pp.22-23. There is a useful short account of flight of historians from repressive European regimes, Nazi Germany included, by Michael Bentley, Modern Historiography: An Introduction, London/New York, 1999, pp.116-26.

110 'Recolonisation' and 'decolonisation' are central tropes in James Belich, Paradise Reforged: A History of the New Zealanders from the 1880s to the Year 2000, Auckland, 2001.

111 W.J. Gardiner, E.T. Beardsley and T.E. Carter, A History of the University of Canterbury, 1873-1973, Christchurch, 1973, pp.399-402, 473; Keith Sinclair, A History of the University of Auckland, 1883-1983, Auckland, 1983, pp.244-47; Rachel Barrowman, Victoria University of Wellington, 1899-1999: A History, Wellington, 1999, pp.103-07.

112 Although the present discussion is confined to historians, it is worth mentioning that there were four other New Zealand professors in the Coombs Building, where Davidson was based at ANU: W.D. Borrie (Demography), Max Neutze (Urban Research Unit); R. Gerard Ward (Geography) and Derek Freeman (Anthropology). It is a commentary on New Zealand being a 'small world' that Davidson went to kindergarten and VUC with Freeman, and was a fellow student at Waitaki with Borrie. 